\title{
HUBUNGAN TINGKAT PENGETAHUAN DAN SIKAP TENTANG KEJADIAN IKUTAN PASCA IMUNISASI DENGAN KEPATUHAN IBU DALAM MEMBERIKAN IMUNISASI DPT-HB-HIB DI WILAYAH KERJA PUSKESMAS LUBUK BUAYA KOTA PADANG
}

\author{
RELATIONSHIP LEVEL OF KNOWLEDGE AND ATTITUDES \\ ABOUT ADVERSE EVENT FOLLOWING IMMUNIZATION WITH \\ MOTHER COMPLIANCE IN GIVING IMMUNIZATION OF DPT- \\ HB-HIB IN LUBUK BUAYA PUBLIC HEALTH CENTER AREA IN \\ PADANG
}

\author{
Lisa Rahmawati, Mahdalena Prihatin Ningsih \\ Prodi DIII Kebidanan Padang Poltekkes Kemenkes Padang \\ Korespondensi: lisarahmawati2406@gmail.com
}

\begin{abstract}
Based on the health profile of Indonesia in 2016, the number of cases of diphtheria in 2016 CFR (Case Fatality Rate) diphtheria, namely by 5.8\%. Of all cases of diphtheria, amounting to $51 \%$ of them do not get vaccinated. Known from the annual report of Padang City Health Department 2017 Immunization coverage DPT-HB-Hib lows are in Lubuk Buaya Public Health Center (70.26\%) of the 95\% targets. The aim of research to determine the relationship level of knowledge and attitude about AEFI with Mother Compliance in giving immunization of DPT-HB-Hib in Lubuk Buaya Public Health Center. This research method is analytical survey with cross sectional study, data collection was done on January 22-March 12, 2019 in Lubuk Buaya Public Health Center. The population was mothers with babies aged 3-9 months, using a sampling technique purposive sampling with a sample of 66 respondents. Collecting data using questionnaires. Data were analyzed using a computerized with chi-square test. Results of univariate analysis obtained $60.6 \%$ of mothers do not obey the immunization of DPT$\mathrm{HB}-\mathrm{Hib}, 51.5 \%$ of mothers good knowledge, $56.1 \%$ of women have a negative attitude and $87.9 \%$ of infants with AEFI DPT-HB-Hib fever. The results of the bivariate analysis contained levels of knowledge about AEFI relationship with Compliance mother in immunization of DPT-HB-Hib $(p=0.002)$ and there is a relationship with Compliance AEFI Attitudes about Women in Giving Immunization DPT-HB-Hib $(p=0.039)$. It was concluded that there is a relationship between the level of knowledge and attitudes about AEFI maternal immunization compliance in providing the DPT-HB-Hib. For that is expected to increase outreach health workers about the DPT-HB-Hib and AEFI in order to minimize the perception and poor view of the DPT-HB-Hib and AEFI.
\end{abstract}

Keywords: Immunization DPT-HB-Hib, Level of Knowledge, Attitude, AEFI 


\begin{abstract}
ABSTRAK
Berdasarkan Profil kesehatan indonesia tahun 2016, jumlah kasus difteri pada tahun 2016 CFR (Case Fatality Rate) difteri yaitu sebesar 5,8\%. Dari seluruh kasus difteri, sebesar $51 \%$ diantaranya tidak mendapatkan vaksinasi. Diketahui dari laporan tahunan Dinas Kesehatan Kota Padang 2017, cakupan Imunisasi DPT-HB-Hib terendah berada pada wilayah kerja Puskesmas Lubuk Buaya (70,26\%) dari 95\% target. Tujuan penelitian untuk mengetahui Hubungan Tingkat Pengetahuan dan Sikap tentang KIPI DPT-HB-Hib dengan Kepatuhan Ibu dalam Memberikan Imunisasi DPT-HB-Hib di wilayah kerja Puskesmas Lubuk Buaya Kota Padang Tahun 2019. Metode Penelitian ini adalah Survei Analitik dengan pendekatan cross sectional, pengumpulan data dilakukan pada 22 Januari-12 Maret 2019 di wilayah kerja Puskesmas Lubuk Buaya. Populasi adalah ibu yang memiliki bayi yang berusia 3-9 bulan, teknik pengambilan sampel menggunakan Purposive Sampling dengan jumlah sampel 66 responden. Pengumpulan data menggunakan kuesioner. Data dianalisis menggunakan komputerisasi dengan uji Chi-square. Hasil analisis univariat diperoleh $60,6 \%$ ibu tidak patuh dalam pemberian imunisasi DPT-HB-Hib, 51,5\% ibu berpengetahuan baik, 56,1\% ibu memiliki sikap negatif dan $87,9 \%$ bayi yang mengalami KIPI DPT-HB-Hib demam. Hasil analisis bivariat terdapat Hubungan Tingkat Pengetahuan tentang KIPI dengan Kepatuhan Ibu dalam Pemberian Imunisasi DPT-HB-Hib $(p=0,002)$ dan terdapat Hubungan Sikap tentang KIPI dengan Kepatuhan Ibu dalam Memberikan Imunisasi DPT-HB-Hib $(p=0,039)$. Disimpulkan bahwa terdapat hubungan tingkat pengetahuan dan sikap tentang KIPI imunisasi dengan kepatuhan ibu dalam memberikan imunisasi DPT-HBHib. Untuk itu diharapkan petugas kesehatan dapat meningkatkan penyuluhan tentang imunisasi DPT-HB-Hib dan KIPI sehingga dapat meminimalisir persepsi dan pandangan buruk terhadap imunisasi DPT-HB-Hib dan KIPI.
\end{abstract}

\title{
Kata Kunci: Imunisasi DPT-HB-Hib, Tingkat Pengetahuan, Sikap, KIPI
}

\section{PENDAHULUAN}

Imunisasi adalah suatu upaya untuk menimbulkan atau meningkatkan kekebalan seseorang secara aktif terhadap suatu penyakit, sehingga apabila suatu saat terpajan dengan penyakit tersebut tidak akan sakit atau hanya mengalami sakit ringan. Angka kematian bayi dan balita yang tinggi di Indonesia menyebabkan turunnya derajat kesehatan masyarakat, salah satu upaya untuk mengatasi masalah ini adalah program pemberian imunisasi dasar bagi bayi dan balita secara lengkap. Imunisasi penting untuk mencegah penyakit berbahaya, salah satunya adalah imunisasi DPT (Difteri, Pertusis, Tetanus). Saat ini imunisasi DPT sudah dikombinasikan dengan vaksin lain yaitu HB-Hib sehingga imunisasi DPT menjadi imunisasi DPTHB-Hib atau yang disebut dengan imunisasi pentavalen yang mana vaksin pentavalen berfungsi mencegah 
beberapa jenis penyakit, yaitu difteri, pertussis, tetanus, hepatitis $\mathrm{B}$, radang otak dan radang paru.

Namun, seiring dengan cakupan imunisasi yang tinggi maka penggunaan vaksin juga meningkat dan sebagai akibatnya reaksi simpang yang berhubungan dengan imunisasi juga meningkat. Reaksi simpang dikenal dengan istilah kejadian ikutan pasca imunisasi (KIPI) atau adverse events following immunization (AEFI). Program imunisasi yang sudah berjalan sejak lama di Indonesia, akhir-akhir ini mendapatkan hambatan dengan merebaknya informasi yang tidak benar mengenai imunisasi sehingga banyak orangtua ragu dan takut mengimunisasi bayinya. Informasi yang tidak benar seringkali menggunakan isu ketakutan (fear mongering) terhadap Kejadian Ikutan Pasca Imunisasi (KIPI) yang mungkin dapat terjadi pada anak setelah mendapatkan imunisasi.

Berdasarkan profil kesehatan Indonesia tahun 2016, jumlah kasus difteri pada tahun 2016 sebanyak 415 kasus dengan jumlah kasus meninggal sebanyak 24 kasus sehingga CFR (Case Fatality Rate) difteri yaitu sebesar $5,8 \%$. Dari seluruh kasus difteri, sebesar $51 \%$ diantaranya tidak mendapatkan vaksinasi. Pada tahun 2016, dilaporkan terdapat 33 kasus dari 7 provinsi dengan jumlah meninggal 14 kasus atau CFR 42,4\%. Menurut status imunisasi sebanyak 23 kasus $(69,7 \%)$ terjadi pada kelompok yang tidak diimunisasi.

Kasus KIPI memang sering terjadi pada setiap imunisasi, salah satunya imunisasi DPT. Kebanyakan anak menderita panas setelah mendapat imunisasi DPT, tetapi itu adalah hal yang wajar, namun seringkali ibu-ibu tegang, cemas dan khawatir. Banyak ibu yang cemas sekali karena timbul bengkak di bekas tempat suntikan. Untuk anak yang memiliki riwayat kejang demam, imunisasi DPT tetap aman dan tidak membahayakan. Adapun penyebab kecemasan ibu dikarenakan pemberitaan miring tentang efek imunisasi.

Berdasarkan penelitian Dwi dan Ian (2018), tentang Hubungan Pengetahuan dan Sikap Ibu dengan Kepatuhan dalam mengikuti imunisasi Measles-Rubella (MR) massal di Posyandu Wilayah Kerja Puskesmas Nganglik II Kabupaten Sleman Yogyakarta, ditemukan hasil bahwa terdapat hubungan pengetahuan dengan kepatuhan dalam pelaksanaan imunisasi MR dan terdapat hubungan sikap 
dengan kepatuhan dalam pelaksanaan imunisasi MR.

Sedangkan menurut Penelitian Yudi, Atty dan Ragil (2017), tentang Hubungan Pengetahuan Ibu tentang Kejadian Ikutan Pasca Imunisasi Dasar dengan kepatuhan Ibu dalam memberikan imunisasi dasar pada bayi di Kelurahan Tlogomas Malang, hasil analisis data diperoleh temuan sebanyak 18 responden (60\%) mempunyai pengetahuan yang baik mengenai KIPI dasar dan 27 responden (90\%) patuh memberikan imunisasi dasar pada bayinya.

Berdasarkan hasil Riset Kesehatan Dasar tahun 2013 persentase anak umur 12-23 bulan yang mendapatkan imunisasi dasar berdasarkan provinsi di Indonesia yaitu 59,2\%, pada tahun 2013 meningkat dari 53,8\% pada tahun 2010 dan $41,6 \%$ pada tahun 2007. Meskipun terjadi peningkatan pencapaian imunisasi dasar berdasarkan provinsi di Indonesia pada tahun 2013, namun pada persentase imunisasi DPT - HB 3 adalah 75,6 \% dengan kasus imunisasi terendah. Sumatera Barat salah satu provinsi yang kurang dari rata-rata nasional dengan prevalensi $60,2 \%$ yang menerima imunisasi DPT-HB-Hib 3.
Berdasarkan laporan tahunan Dinas Kesehatan Kota Padang 2017, cakupan imunisasi DPT-HB-Hib terendah berada pada wilayah kerja Puskesmas Lubuk Buaya $(70,26 \%)$ dari 95\% target yang ada di antara 23 Puskesmas yang ada di Kota Padang. Hasil survei pendahuluan yang dilakukan di wilayah kerja Puskesmas Lubuk Buaya, sebanyak 8 dari 10 responden patuh dalam melakukan imunisasi DPT-HB-Hib yaitu mengimunisasi anaknya sesuai jadwal dan status imunisasi DPT-HB-Hib yang lengkap, sedangkan 2 diantaranya tidak patuh dalam melakukan imunisasi DPTHB-Hib seperti status imunisasi DPTHB-Hib yang tidak lengkap, tidak datang sesuai jadwal, dan sebagainya. Ketidakpatuhan responden disebabkan oleh beberapa hal terkait dengan isu-isu negatif tentang imunisasi DPT-HB-Hib kejadian ikutan pasca imunisasi, yang menyebabkan responden jadi ragu atau takut untuk mengimunisasi anaknya untuk kedepan. Pada saat dilakukan wawancara masih banyak ibu yang tidak mengetahui manfaat dari imunisasi DPT-HB-Hib, reaksi KIPI DPT-HB-Hib dan penanganan terhadap KIPI DPT-HB-Hib. 
Dari segi pengetahuan, sebanyak 4 dari 10 orang ibu memiliki pandangan miring terhadap imunisasi DPT-HB-Hib karena anaknya jatuh sakit sehabis imunisasi dan ragu untuk melanjutkan imunisasi selanjutnya, kemudian ibu beralasan bahwa tidak mengerti dengan penjelasan yang diberikan petugas kesehatan sehingga ibu bingung terhadap KIPI yang terjadi pada bayinya.

Berdasarkan uraian di atas maka peneliti merasa perlu melakukan penelitian tentang hubungan tingkat pengetahuan dan sikap tentang kejadian ikutan pasca imunisasi dengan kepatuhan ibu dalam memberikan imunisasi DPT-HB-Hib di wilayah kerja
Puskesmas Lubuk Buaya Kota Padang tahun 2019.

\section{METODE}

Jenis penelitian yang digunakan yaitu survey analitik dengan pendekatan cross sectional. Populasi dalam penelitian ini adalah seluruh ibu yang memiliki bayi usia 3-9 bulan yang sudah diberi imunisasi DPT-HB-Hib yang ada di wilayah kerja Puskesmas Lubuk Buaya. Jumlah sampel dalam penelitian ini berjumlah 66 orang. Teknik pengambilan sampel dengan menggunakan teknik purposive sampling. Data dikumpulkan menggunakan kuesioner. Pengolahan data secara univariat dan bivariat menggunakan chi-square.

\section{HASIL DAN PEMBAHASAN}

\section{Analisis Univariat}

Tabel 1 Distribusi frekuensi Kepatuhan Ibu dalam Memberikan Imunisasi DPTHB-Hib di Wilayah Kerja Puskesmas Lubuk Buaya Kota Padang

\begin{tabular}{ccc}
\hline Imunisasi DPT-HB-Hib & f & \% \\
\hline Tidak Patuh & 40 & 60,6 \\
Patuh & 26 & 39,4 \\
\hline Jumlah & 66 & 100 \\
\hline
\end{tabular}

Berdasarkan tabel 1 diketahui dari 66 responden terdapat 40 responden $(60,6 \%)$ yang tidak patuh dalam pemberian imunisasi DPT-HB-Hib. 
Tabel 2 Distribusi Frekuensi Tingkat Pengetahuan Tentang Kejadian Ikutan Pasca Imunisasi dengan Kepatuhan Ibu Dalam Memberikan Imunisasi DPT-HB-Hib di Wilayah Kerja Puskesmas Lubuk Buaya Kota Padang

\begin{tabular}{ccc}
\hline Tingkat Pengetahuan & f & \% \\
\hline Kurang & 32 & 48,5 \\
Baik & 34 & 51,5 \\
\hline Jumlah & 66 & 100 \\
\hline
\end{tabular}

Berdasarkan tabel 2 diketahui dari 66 responden terdapat 34 responden $(51,5 \%)$ memiliki tingkat pengetahuan baik.

Tabel 3 Distribusi Frekuensi Sikap Ibu Tentang Kejadian Ikutan Pasca Imunisasi dengan Kepatuhan Ibu Dalam Memberikan Imunisasi DPT-HB-Hib di Wilayah Kerja Puskesmas Lubuk Buaya Kota Padang

\begin{tabular}{cccc}
\hline Sikap & f & \% \\
\hline Negatif & 37 & 56,1 \\
Positif & 29 & 43,9 \\
\hline Jumlah & 66 & 100 \\
\hline
\end{tabular}

Berdasarkan tabel 3 diketahui dari 66 responden terdapat 37 responden $(56,1 \%)$ memiliki sikap negatif terhadap imunisasi DPT-HB-Hib.

Tabel 4 Distribusi frekuensi Kejadian Ikutan Pasca Imunisasi DPT-HB-Hib di Wilayah Kerja Puskesmas Lubuk Buaya Kota Padang

\begin{tabular}{ccc}
\hline KIPI DPT-HB-Hib & f & \% \\
\hline Demam & 58 & 87,9 \\
Bengkak & 38 & 57,6 \\
Kemerahan & 20 & 30,3 \\
Muntah & 2 & 3 \\
Kejang & - & - \\
\hline Jumlah & 66 & 100 \\
\hline
\end{tabular}

Berdasarkan tabel 4 diketahui dari 66 bayi kejadian ikutan pasca imunisasi DPT-HBHib paling banyak adalah demam yaitu sebanyak 58 bayi $(87,9 \%)$. 


\section{Analisis Bivariat}

Tabel 5 Distribusi Frekuensi Hubungan Tingkat Pengetahuan tentang Kejadian Ikutan Pasca Imunisasi dengan Kepatuhan Ibu Dalam Memberikan Imunisasi DPT-HB-Hib di Wilayah Kerja Puskesmas Lubuk Buaya Kota Padang

\begin{tabular}{|c|c|c|c|c|c|c|c|}
\hline \multirow{3}{*}{$\begin{array}{c}\text { Tingkat } \\
\text { Pengetahuan }\end{array}$} & \multicolumn{4}{|c|}{ Kepatuhan Imunisasi DPT-HB-Hib } & \multirow{2}{*}{\multicolumn{2}{|c|}{ Jumlah }} & \multirow{3}{*}{ p value } \\
\hline & \multicolumn{2}{|c|}{ Tidak Patuh } & \multicolumn{2}{|c|}{ Patuh } & & & \\
\hline & $\mathbf{f}$ & $\%$ & f & $\%$ & f & $\%$ & \\
\hline Kurang & 26 & 81,3 & 6 & 18,8 & 32 & 100 & \\
\hline Baik & 14 & 41,2 & 20 & 58,8 & 34 & 100 & 0,002 \\
\hline Jumlah & 40 & 60,6 & 26 & 39,4 & 66 & 100 & \\
\hline
\end{tabular}

Berdasarkan Tabel 5 diketahui dari 32 responden dengan tingkat pengetahuan kurang baik terdapat 26 responden $(81,3 \%)$ yang tidak patuh dalam melakukan imunisasi DPT-HBHib. Berdasarkan hasil uji statistik didapatkan $p$ value sebesar 0,002 $(\mathrm{p}<0,05)$ maka $\mathrm{H}_{0}$ ditolak $\mathrm{H}_{\mathrm{a}}$ diterima artinya ada hubungan antara tingkat pengetahuan tentang kejadian ikutan pasca imunisasi dengan kepatuhan ibu dalam memberikan imunisasi DPT HB - HiB pada bayi.

Penelitian ini sejalan dengan penelitian yang dilakukan oleh Yudi dkk mengenai hubungan pengetahuan ibu tentang kejadian ikutan pasca imunisasi dasar dengan kepatuhan ibu dalam memberikan imunisasi dasar pada bayi di Kelurahan Tlogomas Malang tahun 2017 menunjukkan adanya hubungan antara pengetahuan ibu dengan kepatuhan ibu dalam memberikan imunisasi.

Pengetahuan merupakan hasil dari tahu dan ini terjadi setelah seseorang melakukan pengindraan terhadap suatu objek tertentu. Pengindraan sendiri terjadi melalui panca indera manusia yang terdiri dari indera penglihatan, indera pendengaran, indera penciuman, indera perabaan dan indera pengecapan. Perilaku yang didasari oleh pengetahuan akan lebih tahan lama dari perilaku yang tidak didasari pengetahuan.

Menurut asumsi peneliti, pengetahuan tentang imunisasi DPTHB-Hib dan kejadian ikutan pasca imunisasi pada umumnya diperoleh penyuluhan-penyuluhan tentang imunisasi DPT-HB-Hib dan kejadian ikutan pasca imunisasi yang dilakukan oleh tenaga kesehatan. Pengindraan 
yang dilakukan oleh ibu untuk memperoleh pengetahuan dari penyuluhan-penyuluhan adalah mendengarkan. Sedangkan pengetahuan tentang imunisasi DPT-HB-Hib dan kejadian ikutan pasca imunisasi ini tidak hanya dapat diperoleh ibu dari pengindraan pendengaran saja, juga dapat diperoleh dari membaca buku KIA dan buku-buku lain yang berhubungan dengan imunisasi DPTHB-Hib, informasi dari gadget yang berhubungan dan menjelaskan tentang imunisasi DPT-HB-Hib dan kejadian ikutan pasca imunisasi.

Ini terbukti dari data univariat pada variabel pengetahuan yaitu terdapat 40 responden $(60,6 \%)$ menjawab salah butir soal nomor 5 tentang penyakit yang dapat dcegah dengan imunisasi DPT-HB-Hib. Apabila Ibu memanfaatkan sumber informasi yang bisa dijangkau, kemungkinan ibu akan memiliki pengetahuan yang baik tentang imunisasi DPT-HB-Hib dan Kejadian Ikutan Pasca Imunisasi tersebut.

Oleh karena itu, pengetahuan dan informasi mengenai imunisasi DPTHB-Hib dan kejadian ikutan pasca imunisasi sebaiknya tidak hanya diterima dari penyuluhan-penyuluhan yang diberikan oleh tenaga kesehatan dan membaca buku KIA saja, namun ibu juga harus berusaha memanfaatkan media informasi lainnya seperti bukubuku, atau media informasi seperti televisi dan lain lainnya, dan para tokoh masyarakat seperti kader juga harus bisa untuk memberikan informasi ataupun pengetahuan terbaru mengenai imunisasi karena kader merupakan bagian dari tokoh masyarakat yang bertanggung jawab sebagai penyalur informasi kedua setelah tenaga kesehatan, sehingga memori akan materi imunisasi DPT-HB-Hib dan kejadian ikutan pasca imunisasi lebih cepat diserap oleh ibu dan berdampak pada peningkatan pengetahuan ibu. Serta motivasi dalam diri ibu untuk menuju derajat kesehatan haruslah ditingkatkan dengan mengaplikasikan pengetahuan-pengetahuan yang ia miliki termasuk tentang imunisasi DPTHB-Hib dan kejadian ikutan pasca imunisasi. 


\section{Tabel 6 Distribusi Frekuensi Hubungan Sikap Tentang Kejadian Ikutan Pasca Imunisasi dengan Kepatuhan Ibu Dalam Memberikan Imunisasi DPT-HB- Hib di Wilayah Kerja Puskesmas Lubuk Buaya Kota Padang}

\begin{tabular}{|c|c|c|c|c|c|c|c|}
\hline \multirow{3}{*}{ Sikap } & \multicolumn{4}{|c|}{ Kepatuhan Imunisasi DPT-HB-Hib } & \multirow{2}{*}{\multicolumn{2}{|c|}{ Jumlah }} & \multirow{3}{*}{ p value } \\
\hline & \multicolumn{2}{|c|}{ Tidak Patuh } & \multicolumn{2}{|c|}{ Patuh } & & & \\
\hline & $\mathbf{f}$ & $\%$ & $\mathbf{f}$ & $\%$ & $\mathbf{f}$ & $\%$ & \\
\hline Negatif & 27 & 73 & 10 & 27 & 37 & 100 & \\
\hline Positif & 13 & 44,8 & 16 & 55,2 & 29 & 100 & 0,039 \\
\hline Jumlah & 40 & 60,6 & 26 & 39,4 & 66 & 100 & \\
\hline
\end{tabular}

Berdasarkan tabel 6 diketahui dari 37 responden dengan sikap ibu yang negatif tentang kejadian ikutan pasca imunisasi terdapat 27 responden (73\%) yang tidak patuh dalam melakukan imunisasi DPT-HB-Hib. Berdasarkan hasil uji statistik didapatkan $p$ value sebesar 0,039 $(\mathrm{p}<0,05)$ maka $\mathrm{H}_{0}$ ditolak $\mathrm{H}_{\mathrm{a}}$ diterima artinya ada hubungan antara sikap tentang kejadian ikutan pasca imunisasi dengan kepatuhan ibu dalam memberikan imunisasi DPT - HB Hib.

Penelitian ini sejalan dengan penelitian yang dilakukan oleh Dwi Ayu dan Ian Rossalia pada tahun 2017 megenai hubungan pengetahuan dan sikap ibu dengan kepatuhan dalam mengikuti imunisasi measles-rubella (MR) massal di Posyandu wilayah kerja Puskesmas Nganglik II Kabupaten Sleman Yogyakarta tahun 2017 menunjukkan adanya hubungan antara sikap ibu dengan kepatuhan dalam mengikuti imunisasi measles-rubella (MR).

Sikap responden dalam penelitian ini secara khusus merupakan tanggapan responden yang berhubungan dengan pelaksanaan imunisasi DPTHB-Hib untuk anak. Sikap merupakan reaksi yang masih tertutup dari seseorang terhadap suatu objek. Manifestasi sikap itu tidak dapat ditafsirkan terlebih dahulu dari perilaku yang tertutup. Sikap secara nyata menunjukkan konotasi adanya kesesuaian reaksi stimulus tertentu yang dalam kehidupan sehari-hari merupakan reaksi yang bersifat emosional terhadap stimulus sosial.

Menurut asumsi peneliti, yang melatar belakangi responden dengan status imunisasi DPT-HB-Hib tidak patuh memiliki sikap negatif yaitu sebanyak $73 \%$ responden terhadap imunisasi DPT-HB-Hib dan kejadian 
ikutan pasca imunisasi adalah kurangnya pengetahuan responden tentang imunisasi DPT-HB-Hib dan kejadian ikutan pasca imunisasi tersebut, serta kurangnya keinginan responden untuk menggali informasiinformasi lebih tentang imunisasi DPTHB-Hib dan kejadian ikutan pasca imunisasi. Seperti yang diketahui dari data univariat pada variabel, terdapat $31,82 \%$ responden yang memiliki sikap negatif terhadap imunisasi DPT-HBHib dan Kejadian Ikutan Pasca Imunisasi cenderung memilih untuk membawa anak ke poyandu/ posyandu untuk diimunisasi tanpa seizin suami dengan menjawab setuju dan sangat setuju pada butir pertanyaan nomor 7 (unfavourable).

Salah satu komponen dari sikap adalah keyakinan atau kepercayaan. Keyakinan akan adanya zat-zat haram dan berbahaya didalam vaksin imunisasi DPT-HB-Hib dan adanya kejadian ikutan pasca imunisasi sehabis imunisasi DPT-HB-Hib membuat ibu bahkan memberhentikan bahkan tidak memberikan imunisasi DPT-HB-Hib pada anak.

Ketakutan responden akan vaksin yang digunakan mengandung zat haram dan berbahaya juga ditimbulkan karena kurangnya keiinginan responden untuk memastikan kebenaran isu-isu tersebut, seperti dengan cara bertanya kepada tenaga kesehatan ataupun kader-kader kesehatan yang ada di masyarakat. Sehingga ibu bahkan keluarga tidak tahu tentang kebenaran isu-isu tersebut dan meningkatkan ketidakpatuhan dalam pemberian imunisasi DPT-HBHib anak. Hal lainnya yang menyebabkan ibu percaya akan hal tersebut dikarenakan ketidak terpaparan ibu dengan informasi-informasi yang meluruskan isu-isu yang mungkin terjadi.

Maka dari itu, perlu adanya penyeimbangan antara sikap masyarakat dan pengetahuan masyarakat beserta peran tenaga kesehatan untuk bisa meyakinkan masyarakat mengenai imunisasi DPT-HB-Hib dan menghilangkan isu-isu buruk terkait dengan imunisasi DPT-HB-Hib dan kejadian ikutan pasca imunisasi. Sikap ibu terhadap imunisasi DPT-Hb-Hib dan kejadian ikutan pasca imunisasi dapat diarahkan ke arah yang lebih baik dengan usaha pemberian layanan imunisasi yang semakin baik. Untuk pengetahuan yaitu dengan memberikan tambahan-tambahan informasi tentang imunisasi DPT-HB-Hib dan kejadian 
ikutan pasca imunisasi, termasuk juga meminimalkan kejadian ikutan pasca imunisasi DPT-Hb-Hib seperti anjuran memberikan obat penurun panas, kompres hangat pada daerah bekas suntikan, beri anak banyak minum, hindari penekanan pada daerah bekas suntikan dan konseling tentang semua gejala akan hilang dengan sendirinya dalam beberapa hari saja.

\section{SIMPULAN}

Lebih dari separuh $(60,6 \%)$ ibu bayi tidak patuh dalam pemberian imunisasi DPT-HB-Hib, lebih dari separuh $(51,5 \%)$ ibu bayi memiliki pengetahuan yang baik tentang kejadian ikutan pasca imunisasi dengan kepatuhan ibu dalam pemberian imunisasi DPT-HB-Hib, lebih dari separuh $(56,1 \%)$ ibu bayi memiliki sikap negatif tentang kejadian ikutan pasca imunisasi dan imunisasi DPTHB-Hib, Sebagian besar $(87,9 \%)$ bayi mengalami kejadian ikutan pasca imunisasi DPT-HB-Hib demam, ada hubungan pengetahuan ibu tentang kejadian ikutan pasca imunisasi dengan kepatuhan ibu dalam memberikan imunisasi DPT-HB-Hib, ada hubungan sikap ibu tentang kejadian ikutan pasca imunisasi dengan kepatuhan ibu dalam memberikan imunisasi DPT-HB-Hib.

\section{DAFTAR PUSTAKA}

Kementerian Kesehatan RI. Buku Ajar Imunisasi. Jakarta : Kementerian Kesehatan RI; 2014.

Widyastuti, Ririn. Hubungan Pengetahuan dan Sikap Ibu Balita dengan Kejadian Ikutan Pasca Imunisasi (KIPI) di Puskesmas Oebobo (jurnal). Poltekkes Kemenkes Kupang Program Studi Kebidanan; 2016.

Sari, Eka Susanti. Gambaran Tingkat Pengetahuan Ibu tentang reaksi Kejadian Ikutan Pasca Imunisasi (KIPI) DPT/HB Combo di Posyandu Desa Doyong Kecamatan Miri Kabupaten Sragen (Karya Tulis Ilmiah). Sekolah Tinggi Ilmu Kesehatan Kusuma Husada Surakarta; 2012.

Irmailis, dkk. Peran Petugas Imunisasi dalam Pemberian Vaksinasi (Jurnal). Jurnal Ilmu Keperawatan; 2016.

Marmi, dkk. Asuhan Neonatus, Bayi, Balita, dan Anak Pra Sekolah. Yogyakarta : Pustaka Pelajar; 2012.

Kementerian Kesehatan RI. Profil Kesehatan Indonesia 2016. Jakarta : Kementerian Kesehatan RI; 2017.

Pramitasari, Dwi Ayu dan Puteri, Ian Rossalia Pradita. Hubungan pengetahuan dan Sikap Ibu dengan kepatuhan dalam mengikuti Imunisasi MeaslesRubella (MR) Massal di Posyandu Wilayah Kerja Puskesmas Nganglik II Kabupaten Sleman Yogyakarta (jurnal). Yogyakarta; 2018.

Yudi, dkk. Hubungan Pengetahuan Ibu tentang Kejadian Ikutan Pasca Imunisasi Dasar dengan Kepatuhan Ibu dalam memberikan Imunisasi Dasar 
pada Bayi di Kelurahan Tlogomas Malang (jurnal). Universitas Tribhuwana Tunggadewi; 2017.

Kementerian Kesehatan RI. Riset Kesehatan Dasar 2013. Jakarta; Kementrian Kesehatan RI. 2013.

Dinas Kesehatan Kota Padang. Profil Kesehatan Kota Padang 2017. Padang : Dinas Kesehatan Kota Padang; 2018.

Dinas Kesehatan Kota Padang. Profil Kesehatan Kota Padang 2016. Padang : Dinas Kesehatan Kota Padang; 2017.

Sembiring, Juliana Br. Buku Ajar Neonatus, Bayi, Balita, Anak Pra Sekolah. Yogyakarta : Budi Utama; 2017.

Rezeki, Sri. Pedoman Imunisasi di Indonesia Satgas Imunisasi. Jakarta : IDAI; 2011.

Kementerian Kesehatan RI. Buku Kesehatan Ibu dan Anak. Jakarta : Kementerian Kesehatan RI

Dewi, Vivian Nanny Lia. Asuhan Neonatus bayi dan Anak Balita. Jakarta : Salemba Medika; 2012.

Triwibowo, C dan Pusphandani, ME. Pengantar Dasar Ilmu Kesehatan Masyarakat. Edisi Pertama. Yogyakarta : Nuha Medika; 2015.

Putri, Rachmawati Sukarno. FaktorFaktor yang mempengaruhi Kepatuhan Ibu dalam Memberikan Imunisasi Dasar pada Balita di Dukuh Pilangbangau Desa Sepat Masaran Sragen Tahun 2016 (skripsi). Surabaya : Program Studi Pendidikan Bidan Fakultas Kedokteran Universitas Airlangga; 2016.

Notoadmodjo, Soekidjo. Pendidikan dan Perilaku Kesehatan. Jakarta : Rineka Cipta; 2011.
Notoadmodjo, Soekidjo. Promosi Kesehatan dan Perilaku Kesehatan. Edisi Revisi 2012. Jakarta : Rineka Cipta; 2012.

Wawan dan Dewi M. Pengetahuan, Sikap dan perilaku manusia. Yogyakarta : Nuha Medika; 2011.

Budiman dan Agus R. Kapita Selekta Kuesioner. Jakarta : Salemba Medika; 2013.

Harmoko. Asuhan Keperawatan Keluarga. Yogyakarta : Pustaka Pelajar; 2012.

Riyanto A. Aplikasi Metodologi Penelitian Kesehatan. Jakarta : Rineka Cipta; 2010.

Friedman M, dkk. Buku Ajar Keperawatan Keluarga Riset Teori dan Praktik. Jakarta : Penerbit Buku Kedokteran EGC; 2010.

Azwar, Saifuddin. Sikap manusia, Teori dan Pengukurannya. Jakarta : Pustaka Utama; 2010

Pemerintah Republik Indonesia. Peraturan Pemerintah Republik Indonesia Nomor 33 Tahun 2012. Jakarta : Pemerintah Republik Indonesia; 2012.

Nazir, Moh. Metode Penelitian. Edisi ke-9. Bogor : Ghalia Indonesia; 2014.

Notoadmodjo, Soekidjo. Metodologi Penelitian Kesehatan. Jakarta : Rineka Cipta; 2012.

Dinengsih, Sri dan Heni H. Hubungan Antara Pendidikan, Pengetahuan, Dukungan Keluarga dan Peran Tenaga Kesehatan dengan kepatuhan Ibu dalam melakukan Imunisasi Dasar pada Bayi usia 0-12 bulan di Desa Aweh Kabupaten Lebak Provinsi Banten (jurnal). Prodi D-IV Kebidanan Universitas Nasional Jakarta; 2018 